\title{
Effect of Different Nitrogen Fertilizer Rates and Sources on Vegetative Growth and Yield of Quinoa Plant as a Newly Leafy Vegetable Crop
}

\author{
${ }^{1}$ Ragab, M.E.; S.M. Youssef ${ }^{1}$, Asmaa R. Mahmoud ${ }^{2}$ and Heba M.A. Khater ${ }^{2}$ \\ ${ }^{1}$ Horticulture Dep., Faculty of Agriculture, Ain Shams University, P.O. Box 68, Hadayek Shoubra, 11241, Shoubra El-Kheima, Cairo, Egypt \\ ${ }^{2}$ Vegetable Research Dep., Agricultural \& Biological Research Division, National Research Centre, 33 El-Buhouth St., 12622, Dokki, Giza, Egypt
}

Received: $6 / 9 / 2018$

ABSTRACT: Quinoa (Chenopodium quinoa Willd.) is a pseudocereal that has been cultivated in the Andean region for thousands of years. It is considered as a new non-traditional leafy vegetable crop newly introduced to Egypt. Nitrogen is more important than any other elements for plant growth. It plays a vital role in the growth, yield and nutritional quality of leafy vegetable crops. In order to evaluate the influence of two sources of nitrogen (ammonium sulfate $20.6 \%$ and calcium nitrate $15.5 \%$ ) used at rates of 40,60 and $80 \mathrm{~kg} \mathrm{~N} / \mathrm{fed}$. on vegetative growth and productivity of two quinoa cultivars Cica and Hualhuas harvested after 40 days from sowing date. A field experiment was carried out at the Experimental Farm of the Horticulture Department, Faculty of Agriculture, Ain Shams University, Shoubra El-Kheima, Cairo, Egypt, during the two winter seasons of 2015 and 2016. The treatments were arranged in a split plot design, with three replicates. The obtained results showed that Cica cultivar was superior to Hualhuas concerning all vegetative growth parameters and yield except for leaf area in both seasons of the study. Regarding nitrogen rates and sources, quinoa plants received $80 \mathrm{~kg} \mathrm{~N} / \mathrm{fed}$. from ammonium sulfate or calcium nitrate recorded the highest values of plant length, leaf area, plant fresh and dry weights, and fresh and dry weights of leaves/plant, as well as leaf moisture content without significant differences between the two nitrogen sources. On the other hand, the lowest values were recorded by $40 \mathrm{~kg} \mathrm{~N} / \mathrm{fed}$. from ammonium sulfate or calcium nitrate except for number of leaves/plant in both seasons and leaf moisture content in the second season. However, no significant differences were detected among all nitrogen treatments (rates or sources) on the number of leaves/plant. A higher significant yield was attained by ammonium sulfate at $80 \mathrm{~kg}$ $\mathrm{N} /$ fed. in relative to the rest of nitrogen treatments. Concerning the interaction effect, the results clearly revealed that Cica plants received calcium nitrate at $80 \mathrm{~kg} \mathrm{~N} / \mathrm{fed}$. gave the highest values of plant length. Furthermore, Cica plants treated with $80 \mathrm{~kg} \mathrm{~N} /$ fed. either from ammonium sulfate or calcium nitrate recorded significant increases in plant fresh and dry weights as well as yield without significant differences between them. On the other hand, the best values of leaf area were detected when Hualhuas plants were fertilized by $80 \mathrm{~kg} \mathrm{~N} / \mathrm{fed}$. from ammonium sulfate or calcium nitrate without significant difference between them.

Keywords: Chenopodium quinoa, N. rates and sources, Vegetative growth, Yield.

\section{INTRODUCTION}

Leafy vegetables are essential to human health since they are well-recognized as a cheap source of minerals, vitamins, health promoting agents, and dietary fibers. Furthermore, they are low in fat and calories (Toledo et al., 2003). So they are important components of a healthy diet and could help in preventing the major chronic diseases such as cardiovascular diseases and certain cancers (Patil et al., 2009).

Quinoa (Chenopodium quinoa Willd.), is a member of Amaranthaceae family, cultivated along the Andes, for thousands of years and used as a main staple food until Spanish conquest arrived to Latin America (Brinegar et al., 1996). Its grain has a higher nutritive value than the traditional cereals and it is a promising worldwide plant for human consumption and nutrition (Vega-Gálvez et al., 2010). It could support the global food security during this century as reported by FAO which declared 2013 as the International Year of Quinoa (FAO, 2013). It has been received great interests in the United States, Europe, and Asia as well as all over the world (Jacobsen, 2003; Comai et al., 2007). Quinoa is a good source of protein with well-balanced amino acids and can be used as a nutritional ingredient in many food products (Abugoch, 2009; Gonzalez et al., 2012). Quinoa was introduced as a newly multipurpose crop which can replenish a part of food gap since the crop is tolerance to various harsh environmental conditions (Hariadi et al., 2011; Choukr-Allah et al., 2016). It has a variety of uses in the food, feed, food processing and other non-food/industrial uses (Bhargava et al., 2006). In addition, the leaves are eaten as a vegetable. Quinoa leaves are generally lobed or pubescent. They are different in their color (green, red, purple), with the reddish color due to the presence of betacyanins, a type of betalains (Gallardo et al., 2000). The edges of the leaves may be smooth, toothed or serrated (Bhargava et al., 2007). They are typically cooked and served as a side dish, similar to amaranth leaves (Mlakar et al., 2010) or to spinach. In this study, quinoa is introduced as a newly vegetable crop for the first time in Egypt.

For newly introduced crops, it is necessary to assess the appropriate agricultural practices. Amongst many others, the nutritional requirements of the crop are considered to be the most important factor. Nitrogen is generally the most limiting nutrient factor for the growth of leafy vegetables including quinoa which is characterized by a short-life cycle plants and a considerable high requirement for nitrogen nutrition. Nitrogen which constitutes $2-4 \%$ of plant dry matter is one of the macronutrients that required by all plants in comparatively larger amounts than other elements. It is a constituent of many organic compounds found in living cells, such as chlorophyll, nucleic acids (nitrogenous bases), amino acids, enzymes, protein and secondary products (Madan and Munjal, 2009). Farmers have increased the application of nitrogen fertilizers to their lands without considering the response of different species to $\mathrm{N}$ rates and forms. For efficient fertilizer use 
of nitrogen, adequate rate and appropriate source during the crop growth cycle are important (Fageria et al., 2006).

The adequate supply of nitrogen can promote plant growth and increase crop yield, but excessive and inappropriate use of chemical nitrogen fertilizers causes accumulation of unwanted compounds in the edible part of the plant which have a detrimental impact on human health. Moreover, the excessive supply of nitrogen causes ecological problems like nitrate leaching, soil denitrification, ammonia volatilization, and nitrous oxide emissions, which contaminate underground water, air and aggravate the climate change (Neeteson et al., 1999; Wang et al., 2002; Ravishankara et al., 2009; Reay et al., 2012). On the contrary, nitrogen deficiency generally results in stunted growth and chlorotic leaves caused by poor assimilate formation that leads to premature flowering and shortening of the growth cycle (Lincoln and Edvardo, 2006). A nitrogen fertilization requirement of quinoa crop is still under study world widely because of variability of ecological conditions. In this concern, Mujica et al. (2001) stated that quinoa has higher requirements for nitrogen $(\mathrm{N})$ and calcium (Ca), moderate for phosphorous (P), and minimal for potassium $(\mathrm{K})$ and respond strongly to $\mathrm{N}$ fertilization. Similarly, Erley et al. (2005) reported that quinoa is highly responsive to soil nitrogen. The response of nitrogen application on growth, development and yield of two quinoa genotypes were also studied by Basra et al. (2014) who reported that quinoa growth rate of both genotypes was improved with increasing levels of nitrogen (100 and $135 \mathrm{~kg} \mathrm{~N}^{-1}$ ). Recently, Kansomjet et al. (2017) found that $\mathrm{N}$ fertilizer rate at 93.75, 187.5 or $312.5 \mathrm{~kg} \mathrm{~N} \mathrm{ha}^{-1}$ gave the highest values of leaf area index and crop growth rate without significant differences.

Table 1: Physical and chemical properties of the experimental soil

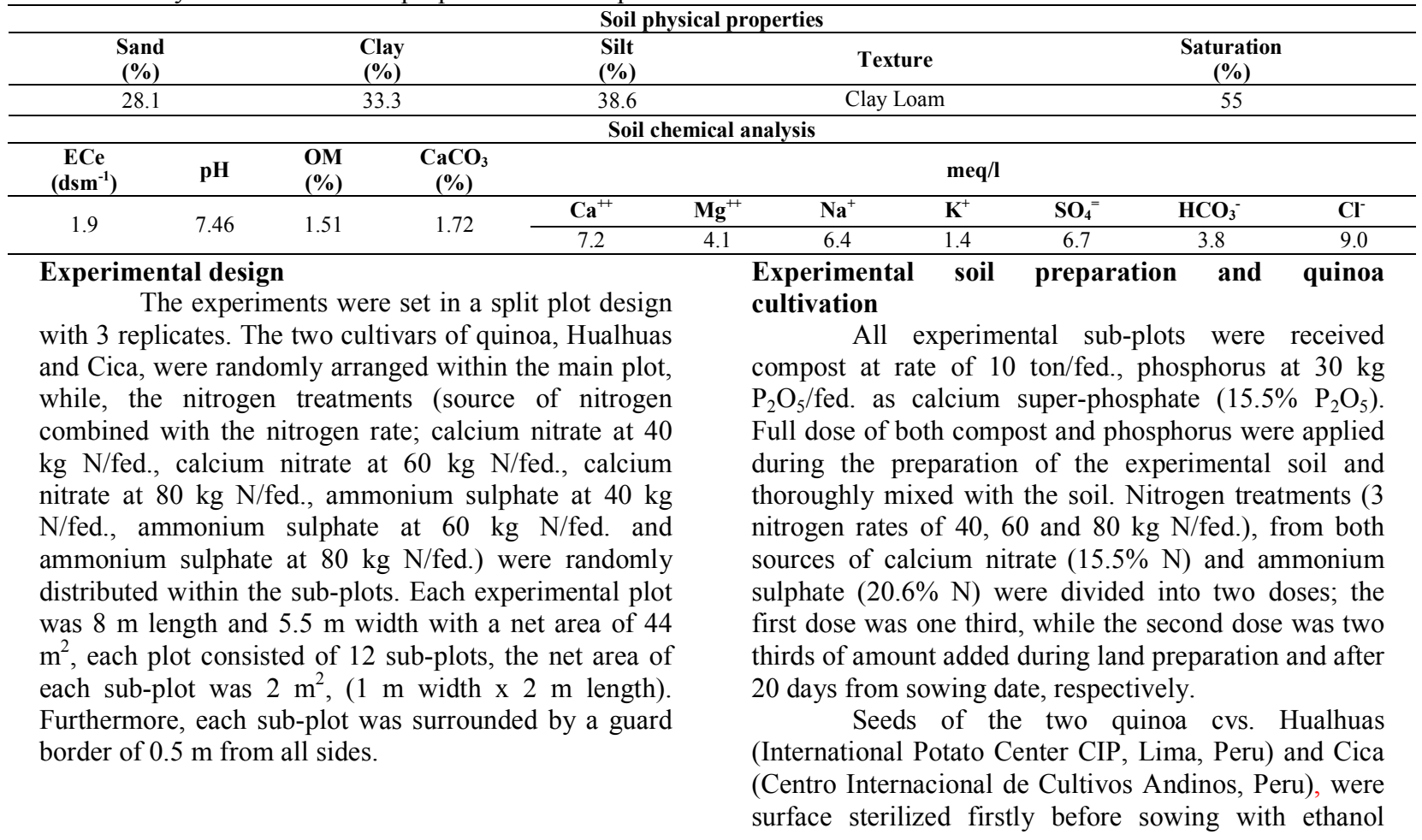

As for the forms of nitrogen, plants can utilize both nitrate $\left(\mathrm{NO}_{3}{ }^{-}\right)$and ammonium $\left(\mathrm{NH}_{4}^{+}\right)$as a nitrogen source (Marschner, 1995). Amongst many $\mathrm{N}$ sources, ammonium sulfate (20.6\%) and calcium nitrate (15.5\%) are used commonly in Egypt. In this regard, Ezzo et al. (2008) found that the cabbage plants fertilized by ammonium sulphate recorded the highest net head weight, net head percent and net yield $\mathrm{m}^{-1}$ than those received ammonium nitrate or urea form. On the contrary, the best source of nitrogen for lettuce was calcium nitrate which resulted insignificant higher yields as compared to ammonium sulfate (Piotr and Kołota, 2011).

The aim of this work was to investigate the effect of different nitrogen rates $(40,60$ and $80 \mathrm{~kg}$ $\mathrm{N} /$ fed.) and sources (ammonium sulphate 20.6\% N$\mathrm{NH}_{4}{ }^{+}$and calcium nitrate $15.5 \% \mathrm{~N}-\mathrm{NO}_{3}{ }^{-}$) on young plant vegetative growth and yield of two quinoa cultivars (Hualhuas and Cica) harvested after 40 days from sowing date as a new leafy vegetable crop in Egypt.

\section{MATERIALS AND METHODS}

The current study was designed to evaluate the effect of nitrogen fertilizer rates and sources on the vegetative growth and yield of two quinoa cultivars as a new non-traditional leafy vegetable crop in Egypt. The study was conducted at the Experimental Farm of the Horticulture Department, the Faculty of Agriculture, Ain Shams University, Shoubra El-Kheima, Cairo, Egypt (latitude $30^{\circ} 06^{\prime} 48^{\prime \prime} \mathrm{N}$ and longitude $31^{\circ} 14^{\prime} 52^{\prime \prime}$ E), during the two successive winter seasons of 2015 and 2016. The physical and chemical properties of the experimental soil are presented in Table 1. 
$70 \%$ for $10 \mathrm{sec}$., then with sodium hypochlorite solution (5\% active chloride) for 10 minutes. Afterward, the seeds were thoroughly washed with a plenty of distilled water several times to ensure complete elimination of chloride traces and then the seeds were dried between two layers of tissue paper. Then seeds were left to dry in air before planting. Washed dried seeds of both quinoa cultivars were sown on the second week of November in both seasons of 2015 and 2016, in rows with $2 \mathrm{~m}$ length and $20 \mathrm{~cm}$ distance between rows with a capacity of 5 rows per each experimental sub-plot. The normal agricultural practices of the regular irrigation, controlling of pest, disease and weed were followed. A plant density was maintained in a range of 275-290 plants $/ \mathrm{m}^{2}$; this has been achieved through seeding rate of about 10 and $15 \mathrm{~g}$ of seeds per each experimental sub-plot of Hualhuas and Cica, respectively. Young quinoa plants of the two quinoa cultivars (Hualhuas and Cica) were randomly harvested after 40 days of sowing date (six weeks later) on the fourth week of December in both seasons of study.

\section{Data recorded}

Twenty five young plants of the two quinoa cultivars (Hualhuas and Cica) were randomly harvested by cutting the plants at the soil surface, in the morning after evaporation of dew from the middle of each experimental sub-plot, 40 days after sowing date. Afterward, harvested plants were transferred to the laboratory for measurement the following vegetative growth parameters:

Plant length: The above ground plant length was recorded in centimeter from the point of contact the plant stem with the soil up to the highest point of the leaves and the average of plant length was calculated.

Number of leaves/plant: The number of leaves per plant was counted and the average number of leaves per plant was calculated.

Leaf area: Average leaf area was calculated as relation

Laf arca $=\frac{\text { Disk area } x \text { No. of disks } x \text { fresh weight of leaves }}{\text { Fresh weight of disks }}$

between area unit and fresh weight of leaves (Koller, 1972) using the following equation:

Plant fresh and dry weights: Plant fresh weight was recorded in gram by using an electronic balance. Afterwards, plants were dried at $70^{\circ} \mathrm{C}$ for 72 hours in an electrical oven supplied with fan and re-weighed to determine plant dry weight.

Fresh and dry weights of leaves/plant: Young quinoa plants were separated into leaves and stem and then the fresh weight of leaves was recorded by using an electronic balance. Separated leaves samples were dried at $70^{\circ} \mathrm{C}$ for 72 hours in an electrical oven supplied with fan and re-weighed to determine dry weight of leaves/plant.

Percentage of leaf moisture content: Moisture leaf content was determined by gravimetric method, using a $5 \mathrm{~g}$ of dried leaves sample to dry in a ventilated oven (Heraeus Instruments, Hanau, Germany) at $102 \pm 2^{\circ} \mathrm{C}$ until constant weight according to AOAC (2005).
Yield: Plant yield was estimated by multiply the average plant fresh weight by the average number of plant per square meter to determine the plant yield $/ \mathrm{m}^{2}$.

\section{Statistical analysis}

All data sets were tabulated and subjected to the statistical analysis of variance procedure using Twoway-ANOVA of the Statistical Package for the Social Sciences software (SPSS Inc., 2008, release 17, Chicago, IL, USA). Values are given as averages of three measurements. Duncan multiple range test was employed to compare the significant differences among means at $P \leq 0.05$ level of significance according to the procedures reported by Gomez and Gomez (1984).

\section{RESULTS}

Plant length, number of leaves/plant and leaf area: Data presented in Table 2 indicated the vegetative growth parameters, i.e. plant length, number of leaves per plant and leaf area of the two quinoa cultivars of Cica and Hualhuas as affected by nitrogen rates of different sources on quinoa young plants harvested at 40 days after sowing, as a new leafy vegetable crop in the winter seasons of 2015 and 2016. It is highly evident that quinoa cv. Cica was superior to Hualhas cultivar in plant length and number of leaves per plant. On the other hand, Hualhuas was superior to Cica cultivar in leaf area parameter. This trend was similar in both seasons of the study.

Concerning the effect of nitrogen rates $(40,60$ and $80 \mathrm{~kg} \mathrm{~N} / \mathrm{fed}$.) of the different sources, ammonium sulfate $(20.6 \%)$ or calcium nitrate $(15.5 \%)$, the treatment of $80 \mathrm{~kg} \mathrm{~N} /$ fed. of calcium nitrate or ammonium sulfate recorded the highest values of plant length in both seasons of the study, along with $60 \mathrm{~kg}$ $\mathrm{N} /$ fed. of calcium nitrate in the second season without significant differences. On the contrary, the lowest values were attained by $40 \mathrm{~kg} \mathrm{~N} / \mathrm{fed}$. of ammonium sulfate treatment in both seasons. The number of leaves/plant showed no significant differences among nitrogen treatments in both seasons, except for $40 \mathrm{~kg}$ $\mathrm{N} /$ fed. of calcium nitrate in the first season. Application of $80 \mathrm{~kg} \mathrm{~N} / \mathrm{fed}$. of calcium nitrate or ammonium sulfate recorded the highest values of average leaf area without a significant difference between them in both growing seasons. Whereas, the lowest value was obtained by 40 $\mathrm{kg} \mathrm{N} /$ fed. of both calcium nitrate and ammonium sulfate in the first and second seasons, respectively.

Regarding the interaction, the combination between the two quinoa cultivars and different nitrogen treatments had significant effects on these parameters in both seasons. Quinoa plants of Cica fertilized with 80 $\mathrm{kg} \mathrm{N} / \mathrm{fed}$. of calcium nitrate recorded the highest significant values $(P \leq 0.05)$ of plant length in relative to the other treatments in both seasons. Furthermore, no significant differences were noticed between all nitrogen treatments with Cica plants on number of leaves per plant in both seasons. However, significant differences were detected between all nitrogen treatments and Hualhuas plants in both seasons. Nitrogen at $80 \mathrm{~kg} \mathrm{~N} / \mathrm{fed}$. of calcium nitrate or ammonium sulfate with Hualhuas cultivar showed the highest significant values of leaf area in both seasons in 
addition to $80 \mathrm{~kg} \mathrm{~N} / \mathrm{fed}$. of calcium nitrate with Cica cultivar in the first season, without significant differences among them.

Plant fresh and dry weights: Data presented in Table 3 revealed that young quinoa plants of Cica cultivar recorded higher significant values of plant fresh and dry weights than young quinoa plants of Hualhuas cultivar in both seasons.

Table 2: Effect of cultivars and nitrogen rates of different sources on plant length, number of leaves and leaf area of quinoa plants harvested at 40 days after sowing, as a new leafy vegetable crop in the winter seasons of 2015 and 2016

\begin{tabular}{|c|c|c|c|c|c|c|c|}
\hline \multirow{2}{*}{\multicolumn{2}{|c|}{ Treatments }} & \multicolumn{2}{|c|}{ Plant length(cm) } & \multicolumn{2}{|c|}{ Number of leaves/plant } & \multicolumn{2}{|c|}{ Leaf area $\left(\mathrm{cm}^{2}\right)$} \\
\hline & & $1^{\text {st }}$ season & $2^{\text {nd }}$ season & $1^{\text {st }}$ season & $2^{\text {nd }}$ season & $1^{\text {st }}$ season & $2^{\text {nd }}$ season \\
\hline \multicolumn{8}{|c|}{ Cultivars } \\
\hline \multirow{2}{*}{\multicolumn{2}{|c|}{$\begin{array}{l}\text { Cica } \\
\text { Hualhuas }\end{array}$}} & $27.82 \mathrm{a}$ & $30.20 \mathrm{a}$ & $11.61 \mathrm{a}$ & $12.5 \mathrm{a}$ & $69.98 \mathrm{~b}$ & $66.83 \mathrm{~b}$ \\
\hline & & $26.69 \mathrm{~b}$ & $26.50 \mathrm{~b}$ & $10.22 \mathrm{~b}$ & $11.56 \mathrm{~b}$ & $74.95 \mathrm{a}$ & $83.09 \mathrm{a}$ \\
\hline \multicolumn{8}{|c|}{ Nitrogen rates of different sources $\left(\mathrm{N}-\mathrm{NH}_{4}^{+} \text {or } \mathrm{N}-\mathrm{NO}_{3}^{-}\right)^{*}$} \\
\hline \multirow{6}{*}{\multicolumn{2}{|c|}{$\begin{array}{l}40 \mathrm{~kg} \mathrm{~N}-\mathrm{NH}_{4}{ }^{+} / \text {fed. } \\
60 \mathrm{~kg} \mathrm{~N}-\mathrm{NH}_{4}^{+} / \text {fed. } \\
80 \mathrm{~kg} \mathrm{~N}-\mathrm{NH}_{4}^{+} / \text {fed. } \\
40 \mathrm{~kg} \mathrm{~N}-\mathrm{NO}_{3}^{-} / \text {fed. } \\
60 \mathrm{~kg} \mathrm{~N}-\mathrm{NO}_{3}^{-} / \text {fed. } \\
80 \mathrm{~kg} \mathrm{~N}-\mathrm{NO}_{3}^{-} / \text {fed. }\end{array}$}} & $23.41 \mathrm{D}$ & $21.80 \mathrm{C}$ & $11.00 \mathrm{~A}$ & $11.83 \mathrm{~A}$ & $64.75 \mathrm{C}$ & $60.00 \mathrm{E}$ \\
\hline & & $26.82 \mathrm{C}$ & $28.03 \mathrm{~B}$ & $11.33 \mathrm{~A}$ & $12.17 \mathrm{~A}$ & $73.38 \mathrm{~B}$ & $72.83 \mathrm{CD}$ \\
\hline & & $29.59 \mathrm{~B}$ & $31.59 \mathrm{~A}$ & $11.33 \mathrm{~A}$ & $11.83 \mathrm{~A}$ & $82.79 \mathrm{~A}$ & $83.97 \mathrm{AB}$ \\
\hline & & $23.75 \mathrm{D}$ & $24.48 \mathrm{C}$ & $10.00 \mathrm{~B}$ & $12.17 \mathrm{~A}$ & $62.14 \mathrm{C}$ & $67.27 \mathrm{D}$ \\
\hline & & $29.06 \mathrm{~B}$ & $30.95 \mathrm{~A}$ & $10.5 \mathrm{AB}$ & $12.17 \mathrm{~A}$ & $69.63 \mathrm{~B}$ & $77.10 \mathrm{BC}$ \\
\hline & & $30.91 \mathrm{~A}$ & $33.25 \mathrm{~A}$ & $11.33 \mathrm{~A}$ & $12.00 \mathrm{~A}$ & $82.1 \mathrm{~A}$ & $88.58 \mathrm{~A}$ \\
\hline \multicolumn{8}{|c|}{ Cultivars x Nitrogen rates of different sources } \\
\hline \multirow{6}{*}{ نَّ } & $40 \mathrm{~kg} \mathrm{~N}-\mathrm{NH}_{4}{ }^{+} /$fed. & $24.31 \mathrm{~d}$ & $22.26 \mathrm{e}$ & $11.67 \mathrm{ab}$ & $12.67 \mathrm{a}$ & $61.24 \mathrm{~g}$ & $53.01 \mathrm{f}$ \\
\hline & $60 \mathrm{~kg} \mathrm{~N}-\mathrm{NH}_{4}^{+} /$fed. & $27.18 \mathrm{c}$ & $28.45 \mathrm{~cd}$ & $12.00 \mathrm{a}$ & $12.67 \mathrm{a}$ & $71.28 \mathrm{de}$ & $61.16 \mathrm{ef}$ \\
\hline & $80 \mathrm{~kg} \mathrm{~N}^{-\mathrm{NH}_{4}}{ }^{+} /$fed. & $29.61 \mathrm{~b}$ & $32.6 \mathrm{bc}$ & $11.67 \mathrm{ab}$ & $12.33 \mathrm{ab}$ & $78.72 \mathrm{bc}$ & $72.81 \mathrm{~cd}$ \\
\hline & $40 \mathrm{~kg} \mathrm{~N}-\mathrm{NO}_{3}{ }^{-} /$fed. & $23.79 \mathrm{~d}$ & $27.3 \mathrm{~d}$ & $10.67 \mathrm{abc}$ & $12.33 \mathrm{ab}$ & $59.97 \mathrm{~g}$ & $58.92 \mathrm{ef}$ \\
\hline & $60 \mathrm{~kg} \mathrm{~N}-\mathrm{NO}_{3}{ }^{-} /$fed. & $29.85 \mathrm{~b}$ & $32.79 \mathrm{~b}$ & $11.67 \mathrm{ab}$ & $12.67 \mathrm{a}$ & $66.39 \mathrm{efg}$ & $74.12 \mathrm{bcd}$ \\
\hline & $80 \mathrm{~kg} \mathrm{~N}-\mathrm{NO}_{3}{ }^{-} /$fed. & $32.18 \mathrm{a}$ & $37.83 \mathrm{a}$ & $12.00 \mathrm{a}$ & $12.33 \mathrm{ab}$ & $82.27 \mathrm{ab}$ & $80.95 \mathrm{bc}$ \\
\hline \multirow{6}{*}{ 鹃 } & $40 \mathrm{~kg} \mathrm{~N} \mathrm{NH}_{4}{ }^{+} /$fed. & $22.51 \mathrm{~b}$ & $21.35 \mathrm{e}$ & $10.33 \mathrm{bc}$ & $11.00 \mathrm{c}$ & $68.26 \mathrm{ef}$ & $66.98 \mathrm{de}$ \\
\hline & $60 \mathrm{~kg} \mathrm{~N}-\mathrm{NH}_{4}^{+} /$fed. & $26.46 \mathrm{c}$ & $27.61 \mathrm{~d}$ & $10.67 \mathrm{abc}$ & $11.67 \mathrm{abc}$ & $75.49 \mathrm{~cd}$ & $84.50 \mathrm{~b}$ \\
\hline & $80 \mathrm{~kg} \mathrm{~N}-\mathrm{NH}_{4}{ }^{+} /$fed. & $29.56 \mathrm{~b}$ & $30.59 \mathrm{bcd}$ & $11.00 \mathrm{ab}$ & $11.33 \mathrm{bc}$ & $86.86 \mathrm{a}$ & $95.15 \mathrm{a}$ \\
\hline & $40 \mathrm{~kg} \mathrm{~N}-\mathrm{NO}_{3}^{-} /$fed. & $23.71 \mathrm{~d}$ & $21.67 \mathrm{e}$ & $9.33 \mathrm{c}$ & $12.00 \mathrm{abc}$ & $64.31 \mathrm{fg}$ & $75.64 \mathrm{bcd}$ \\
\hline & $60 \mathrm{~kg} \mathrm{~N}-\mathrm{NO}_{3}{ }^{-} /$fed. & $28.26 \mathrm{bc}$ & $29.1 \mathrm{bcd}$ & $9.33 \mathrm{c}$ & $11.67 \mathrm{abc}$ & $72.87 \mathrm{cde}$ & $80.08 \mathrm{bc}$ \\
\hline & $80 \mathrm{~kg} \mathrm{~N}-\mathrm{NO}_{3}^{-} /$fed. & $29.63 \mathrm{~b}$ & $28.66 \mathrm{bcd}$ & $10.67 \mathrm{abc}$ & $11.67 \mathrm{abc}$ & $81.93 \mathrm{ab}$ & $96.20 \mathrm{a}$ \\
\hline
\end{tabular}

Means into every group within a column followed by the same letter are not significantly different $(P \leq 0.05)$ according to Duncan's multiple range test.

Table 3: Effect of cultivars and nitrogen rates of different sources on plant fresh and dry weights of quinoa plants harvested at 40 days after sowing, as a new leafy vegetable crop in the winter seasons of 2015 and 2016

\begin{tabular}{|c|c|c|c|c|c|}
\hline \multirow{2}{*}{\multicolumn{2}{|c|}{ Treatments }} & \multicolumn{2}{|c|}{ Plant fresh weight $(\mathrm{g})$} & \multicolumn{2}{|c|}{ Plant dry weight (g) } \\
\hline & & $1^{\text {st }}$ season & $2^{\text {nd }}$ season & $1^{\text {st }}$ season & $2^{\text {nd }}$ season \\
\hline \multicolumn{6}{|c|}{ Cultivars } \\
\hline \multirow{2}{*}{\multicolumn{2}{|c|}{$\begin{array}{l}\text { Cica } \\
\text { Hualhuas }\end{array}$}} & $6.12 \mathrm{a}$ & $6.39 \mathrm{a}$ & $1.65 \mathrm{a}$ & $1.74 \mathrm{a}$ \\
\hline & & $4.60 \mathrm{~b}$ & $5.08 \mathrm{~b}$ & $1.60 \mathrm{~b}$ & $1.66 \mathrm{~b}$ \\
\hline \multicolumn{6}{|c|}{ Nitrogen rates of different sources $\left(\mathrm{N}-\mathrm{NH}_{4}{ }^{+} \text {or } \mathrm{N}-\mathrm{NO}_{3}{ }^{-}\right)^{*}$} \\
\hline \multirow{6}{*}{\multicolumn{2}{|c|}{$\begin{array}{l}40 \mathrm{~kg} \mathrm{~N}-\mathrm{NH}_{4}{ }^{+} / \text {fed. } \\
60 \mathrm{~kg} \mathrm{~N}-\mathrm{NH}_{4}^{+} / \text {fed. } \\
80 \mathrm{~kg} \mathrm{~N}-\mathrm{NH}_{4}^{+} / \text {fed. } \\
40 \mathrm{~kg} \mathrm{~N}-\mathrm{NO}_{3}^{-} / \text {fed. } \\
60 \mathrm{~kg} \mathrm{~N}-\mathrm{NO}_{3}^{-} / \text {fed. } \\
80 \mathrm{~kg} \mathrm{~N}-\mathrm{NO}_{3}^{-} / \text {fed. }\end{array}$}} & $4.64 \mathrm{D}$ & $4.33 \mathrm{C}$ & $1.47 \mathrm{C}$ & $1.49 \mathrm{E}$ \\
\hline & & $5.31 \mathrm{C}$ & $5.85 \mathrm{~B}$ & $1.66 \mathrm{~B}$ & $1.70 \mathrm{C}$ \\
\hline & & $6.80 \mathrm{~A}$ & $6.95 \mathrm{~A}$ & $1.78 \mathrm{~A}$ & $1.86 \mathrm{~A}$ \\
\hline & & $3.87 \mathrm{E}$ & $4.57 \mathrm{C}$ & $1.43 \mathrm{C}$ & $1.57 \mathrm{D}$ \\
\hline & & $5.02 \mathrm{C}$ & $5.66 \mathrm{~B}$ & $1.63 \mathrm{~B}$ & $1.74 \mathrm{~B}$ \\
\hline & & $6.48 \mathrm{~B}$ & $6.93 \mathrm{~A}$ & $1.78 \mathrm{~A}$ & $1.85 \mathrm{~A}$ \\
\hline \multicolumn{6}{|c|}{ Cultivars x Nitrogen rates of different sources } \\
\hline \multirow{6}{*}{$\stackrel{\Xi}{\circlearrowright}$} & $40 \mathrm{~kg} \mathrm{~N}-\mathrm{NH}_{4}^{+} /$fed. & $5.65 \mathrm{c}$ & $4.79 \mathrm{~d}$ & $1.52 \mathrm{de}$ & $1.51 \mathrm{~g}$ \\
\hline & $60 \mathrm{~kg} \mathrm{~N}-\mathrm{NH}_{4}^{+} /$fed. & $6.52 \mathrm{~b}$ & $6.69 \mathrm{~b}$ & $1.65 \mathrm{bc}$ & $1.71 \mathrm{de}$ \\
\hline & $80 \mathrm{~kg} \mathrm{~N}-\mathrm{NH}_{4}^{+} /$fed. & $7.11 \mathrm{a}$ & $7.69 \mathrm{a}$ & $1.78 \mathrm{a}$ & $1.93 \mathrm{a}$ \\
\hline & $40 \mathrm{~kg} \mathrm{~N}-\mathrm{NO}_{3}^{-} /$fed. & $4.36 \mathrm{~d}$ & $4.75 \mathrm{~d}$ & $1.48 \mathrm{ef}$ & $1.61 \mathrm{f}$ \\
\hline & $60 \mathrm{~kg} \mathrm{~N}-\mathrm{NO}_{3}{ }^{-} /$fed. & $5.56 \mathrm{c}$ & $6.53 \mathrm{bc}$ & $1.68 \mathrm{~b}$ & $1.76 \mathrm{bcd}$ \\
\hline & $80 \mathrm{~kg} \mathrm{~N}-\mathrm{NO}_{3}{ }^{-} /$fed. & $7.45 \mathrm{a}$ & $7.86 \mathrm{a}$ & $1.77 \mathrm{a}$ & $1.91 \mathrm{a}$ \\
\hline \multirow{6}{*}{ } & $40 \mathrm{~kg} \mathrm{~N}-\mathrm{NH}_{4}{ }^{+} /$fed. & $3.46 \mathrm{e}$ & $3.88 \mathrm{e}$ & $1.44 \mathrm{fg}$ & $1.47 \mathrm{~g}$ \\
\hline & $60 \mathrm{~kg} \mathrm{~N}-\mathrm{NH}_{4}^{+} /$fed. & $4.11 \mathrm{~d}$ & $5.01 \mathrm{~d}$ & $1.68 \mathrm{~b}$ & $1.68 \mathrm{e}$ \\
\hline & $80 \mathrm{~kg} \mathrm{~N}-\mathrm{NH}_{4}{ }^{+} /$fed. & $6.50 \mathrm{~b}$ & $6.20 \mathrm{bc}$ & $1.78 \mathrm{a}$ & $1.80 \mathrm{~b}$ \\
\hline & $40 \mathrm{~kg} \mathrm{~N}-\mathrm{NO}_{3}^{-} /$fed. & $3.38 \mathrm{e}$ & $4.38 \mathrm{de}$ & $1.37 \mathrm{~g}$ & $1.53 \mathrm{~g}$ \\
\hline & $60 \mathrm{~kg} \mathrm{~N}-\mathrm{NO}_{3}{ }^{-} / \mathrm{fed}$. & $4.48 \mathrm{~d}$ & $4.76 \mathrm{~d}$ & $1.58 \mathrm{~cd}$ & 1.72 cde \\
\hline & 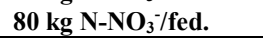 & $5.52 \mathrm{c}$ & $5.99 \mathrm{c}$ & $1.78 \mathrm{a}$ & $1.78 \mathrm{bc}$ \\
\hline
\end{tabular}

Regarding the nitrogen treatments (rates and sources), data in Table 3 exhibited that except for plant fresh weight in the first season, nitrogen fertilizer treatment of $80 \mathrm{~kg} \mathrm{~N} / \mathrm{fed}$. of calcium nitrate or ammonium sulfate gave the highest significant values of plant fresh and dry weights compared to the other nitrogen treatments in both growing seasons without significant differences between them. On the contrary, nitrogen treatments of $40 \mathrm{~kg} \mathrm{~N} /$ fed. either from calcium nitrate or ammonium sulfate recorded the lowest values in both seasons.

The interaction had a significant effect on plant fresh and dry weights in both seasons of the study. Young quinoa plants of Cica cultivar recorded the 
highest significant values of plant fresh and dry weights when fertilized with $80 \mathrm{~kg} \mathrm{~N} /$ fed. of calcium nitrate or ammonium sulfate in both seasons. On the other hand, quinoa plants of Hualhuas cultivar fertilized with $40 \mathrm{~kg}$ $\mathrm{N} /$ fed. of both sources gave the lowest values.

Fresh and dry weights of leaves/plant: The obtained results strongly indicated that young quinoa plants of Cica cultivar harvested at 40 days after seeding gave the higher values of fresh and dry weights of leaves/plant than Hualhuas cultivar in both seasons (Table 4).

Nitrogen treatment at $80 \mathrm{~kg} \mathrm{~N} / \mathrm{fed}$. of calcium nitrate or ammonium sulfate gave significantly the highest values of fresh and dry weights of leaves/plant in both seasons of the study, except for fresh weight of leaves/plant in the second season. The lowest values of leaf fresh and dry weights/plant were attained by $40 \mathrm{~kg}$ $\mathrm{N} /$ fed. of calcium nitrate or ammonium sulfate treatments.

Concerning the interaction effect between the two quinoa cultivars and different nitrogen treatments, significant differences were detected on fresh and dry weights of leaves per plant in both seasons. Leaves of Cica plants harvested after 40 days from seeding showed a significant effect receiving $80 \mathrm{~kg} \mathrm{~N} / \mathrm{fed}$. of calcium nitrate. While, leaves of Hualhuas plants showed a significant effect receiving $80 \mathrm{~kg} \mathrm{~N} /$ fed. either from calcium nitrate or ammonium sulfate during the first season. In the second season, Cica plants fertilized by $80 \mathrm{~kg} \mathrm{~N} / \mathrm{fed}$. of ammonium sulfate gave the highest significant value of fresh weight of leaves compared to the rest of the treatments. In respect of leaf dry weight/plant, quinoa young plants of Cica cultivar treated with $80 \mathrm{~kg} \mathrm{~N} / \mathrm{fed}$. either from calcium nitrate or ammonium sulfate recorded the highest significant values in both seasons, while quinoa young plants of Hualhuas cultivar which received $80 \mathrm{~kg} \mathrm{~N} / \mathrm{fed}$. of ammonium sulfate gave the highest significant values in the first season only.

Leaf moisture content and yield of quinoa plants: Data shown in Table 5 clearly revealed that young quinoa plants of Cica cultivar gave the highest significant values of leaf moisture content and yield in both seasons. However, young quinoa plants of Hualhuas cultivar recorded the highest value of leaf moisture content without significant difference with Cica cultivar in the second season.

Concerning the nitrogen fertilizer treatments, the best results of leaf moisture content were recorded by application of $80 \mathrm{~kg} \mathrm{~N} / \mathrm{fed}$. as calcium nitrate or ammonium sulfate in both seasons. Moreover, the highest yield of plants was obtained by using $80 \mathrm{~kg}$ $\mathrm{N} /$ fed. of ammonium sulfate in both seasons and $80 \mathrm{~kg}$ $\mathrm{N} / \mathrm{fed}$. of calcium nitrate in the second season, without significant differences among them.

Regarding the interaction effect, significant differences effect were detected on leaf moisture content and yield in both seasons (Table 5). Young quinoa plants of Cica fertilized with ammonium sulfate at different rates of 40,60 and $80 \mathrm{~kg} \mathrm{~N} / \mathrm{fed}$. along with Hualhuas plants fertilized with $80 \mathrm{~kg} \mathrm{~N} / \mathrm{fed}$. as calcium nitrate or ammonium sulfate gave the highest significant values of leaf moisture content, without a significant difference among them in the two seasons of the study. As for the yield, Cica cultivar recorded the highest significant values of yield when their plants fertilized with $80 \mathrm{~kg} \mathrm{~N} / \mathrm{fed}$. of both nitrogen sources; calcium nitrate or ammonium sulfate in both seasons, without significant differences between them.

\section{DISCUSSION}

The obtained results herein strongly indicated that young quinoa plants of Cica cultivar harvested at 40 days after seeding gave the vigorous plant vegetative growth and the heaviest plant fresh and dry weights compared with the other studied plants. Furthermore, the vigorous of vegetative growth parameters of Cica cultivar led to a higher plant yield in both seasons. The obtained results may be attributed to varietal difference according to different genetic background or different geographic distribution. In this respect, Tapia (2015) reported that there are five quinoa ecotypes: Valley quinoa, "Altiplano" quinoa, "Salar" quinoa, "Sea level" quinoa, and "Subtropical" quinoa, according to the adaption to different environments, wide variations and a great genetic diversity. The two quinoa cultivars belong to different ecotypes, since Hualhuas is a Peruvian cultivar belonging to a Altiplano type, while Cica is a Peruvian cultivar belonging to a Valley type. In addition, the obtained results are in a good agreement with the results obtained by Ebrahim et al. (2018) who found that Cica cultivar is highly adapted for cultivation under Egyptian conditions.

The above mentioned results for the effect of nitrogen treatments suggested that using calcium nitrate or ammonium sulfate fertilizers as sources of nitrogen at a higher rate of $80 \mathrm{~kg} \mathrm{~N} / \mathrm{fed}$. were the best effective treatment that gave the highest values of the vegetative growth parameters and yield. It is of interest to note that plants have different preference to nitrate and ammonium $\mathrm{N}$ sources. The uptake amount and degree of nitrate and ammonium depended largely on plant types and environmental factors (Hinsinger et al., 2003). The obtained results are in good accordance with Elia et al. (1998) who reported that the presence of both $\mathrm{N}$ $\mathrm{NO}_{3}{ }^{-}$and $\mathrm{N}-\mathrm{NH}_{4}{ }^{+}$improved vegetative growth; but, the best result was obtained with $\mathrm{N}_{-} \mathrm{NO}_{3}^{-}$form which stimulated the vegetative growth. However, the application of $\mathrm{N}^{-\mathrm{NH}_{4}}{ }^{+}$form gave the best dry matter content and yield. In the same respect, nitrogen is playing a significant role as a yield-increasing nutrient for a variety of plants (Cavarianni et al., 2008; Modhej et al., 2008 and Chochura and Kolota, 2011).

Concerning the effect of nitrogen rate, nitrogen supply of leafy vegetable crops, take the superiority as a result of the relatively higher demand from this element; since, it plays an essential role in overall metabolism of plant enzymes activity, building up protoplasm, amino acids and proteins, which induce cell division and initiate meristematic activity (Mirdad, 2009). The increments of plant height of quinoa with increasing $\mathrm{N}$ level are mainly due to role of $\mathrm{N}$ in stimulating metabolic activity which consequently leads to internodes elongation. These results are in agreement with those obtained by Pospisil et al. (2006). 
Insignificant results for the effect of nitrogen rates on number of leaves per plant might be attributed to the leaf number is a genetic factor and it is not widely affected by different treatments. In this concerning, Ghoulam et al. (2002) reported that the number of leaves per plant trait appeared to be less affected parameter in comparison with the other plant growth parameters. In addition, it is worth to mention that nitrogen treatments, improved plant growth and such improvements might be explained on the basis of that nitrogen is an essential element for plant growth, that possibly increased the efficiency of photosynthesis which result in more accumulation of assimilates that caused an increase in the vegetative growth parameters as well as yield (Abd El-Rahman et al., 2001; Shaheen et al., 2012). Application of high $\mathrm{N}$ rates increased the fresh and dry weights of spinach plants (Hammad et al., 2007) and yield (Gülser, 2005).

Table 4: Effect of cultivars and nitrogen rates of different sources on fresh and dry weights of leaves of quinoa plants harvested at 40 days after sowing, as a new leafy vegetable crop in the winter seasons of 2015 and 2016

\begin{tabular}{|c|c|c|c|c|c|}
\hline \multirow{2}{*}{\multicolumn{2}{|c|}{ Treatments }} & \multicolumn{2}{|c|}{ Fresh weight of leaves/plant (g) } & \multicolumn{2}{|c|}{ Dry weight of leaves/plant (g) } \\
\hline & & $1^{\text {st }}$ season & $2^{\text {nd }}$ season & $1^{\text {st }}$ season & $2^{\text {nd }}$ season \\
\hline \multicolumn{6}{|c|}{ Cultivars } \\
\hline \multirow{2}{*}{\multicolumn{2}{|c|}{$\begin{array}{l}\text { Cica } \\
\text { Hualhuas }\end{array}$}} & $2.61 \mathrm{a}$ & $2.81 \mathrm{a}$ & $0.84 \mathrm{a}$ & $0.88 \mathrm{a}$ \\
\hline & & $2.47 \mathrm{~b}$ & $2.66 \mathrm{~b}$ & $0.77 \mathrm{~b}$ & $0.83 \mathrm{~b}$ \\
\hline \multicolumn{2}{|c|}{ Hualhuas } & \multicolumn{4}{|c|}{ Nitrogen rates of different sources $\left(\mathrm{N}-\mathrm{NH}_{4}{ }^{+} \text {or } \mathrm{N}-\mathrm{NO}_{3}\right)^{*}$} \\
\hline & $2.04 \mathrm{C}$ & $2.47 \mathrm{E}$ & $0.72 \mathrm{C}$ & $0.74 \mathrm{D}$ \\
\hline \multicolumn{2}{|c|}{$\begin{array}{l}60 \mathrm{~kg} \mathrm{~N}-\mathrm{NH}_{4}^{+} / \text {fed. } \\
80 \mathrm{~kg} \mathrm{~N}-\mathrm{NH}_{4}^{+} / \text {fed. }\end{array}$} & $2.6 \mathrm{~B}$ & $2.82 \mathrm{C}$ & $0.82 \mathrm{~B}$ & $0.86 \mathrm{~B}$ \\
\hline \multicolumn{2}{|c|}{$80 \mathrm{~kg} \mathrm{~N}-\mathrm{NH}_{4}{ }^{+} /$fed. } & $3.08 \mathrm{~A}$ & $3.27 \mathrm{~A}$ & $0.89 \mathrm{~A}$ & $0.94 \mathrm{~A}$ \\
\hline \multicolumn{2}{|c|}{$40 \mathrm{~kg} \mathrm{~N}-\mathrm{NO}_{3}{ }^{-} /$fed. } & $1.92 \mathrm{C}$ & $2.18 \mathrm{~F}$ & $0.72 \mathrm{C}$ & $0.80 \mathrm{C}$ \\
\hline \multicolumn{2}{|c|}{$60 \mathrm{~kg} \mathrm{~N}-\mathrm{NO}_{3}^{-} /$fed. } & $2.58 \mathrm{~B}$ & $2.63 \mathrm{D}$ & $0.81 \mathrm{~B}$ & $0.88 \mathrm{~B}$ \\
\hline \multicolumn{2}{|c|}{$80 \mathrm{~kg} \mathrm{~N}-\mathrm{NO}_{3}{ }^{-} /$fed. } & $3.02 \mathrm{~A}$ & $3.04 \mathrm{~B}$ & $0.87 \mathrm{~A}$ & $0.93 \mathrm{~A}$ \\
\hline \multicolumn{6}{|c|}{ Cultivars $x$ Nitrogen rates of different sources } \\
\hline \multirow{6}{*}{ 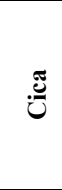 } & $40 \mathrm{~kg} \mathrm{~N}-\mathrm{NH}_{4}^{+} /$fed. & $2.21 \mathrm{f}$ & $2.69 \mathrm{~d}$ & $0.77 \mathrm{~d}$ & $0.76 \mathrm{~d}$ \\
\hline & $60 \mathrm{~kg} \mathrm{~N}-\mathrm{NH}_{4}^{+} /$fed. & $2.67 \mathrm{~cd}$ & $2.93 \mathrm{c}$ & $0.85 \mathrm{bc}$ & $0.86 \mathrm{bc}$ \\
\hline & $80 \mathrm{~kg} \mathrm{~N}-\mathrm{NH}_{4}^{+} /$fed. & $2.96 \mathrm{~b}$ & $3.48 \mathrm{a}$ & $0.91 \mathrm{a}$ & $0.97 \mathrm{a}$ \\
\hline & $40 \mathrm{~kg} \mathrm{~N}-\mathrm{NO}_{3}^{-} /$fed. & $1.97 \mathrm{~g}$ & $2.11 \mathrm{~g}$ & $0.75 \mathrm{~d}$ & $0.83 \mathrm{c}$ \\
\hline & $60 \mathrm{~kg} \mathrm{~N}-\mathrm{NO}_{3}{ }^{-} /$fed. & $2.83 \mathrm{bc}$ & $2.56 \mathrm{e}$ & $0.85 \mathrm{bc}$ & $0.90 \mathrm{~b}$ \\
\hline & $80 \mathrm{~kg} \mathrm{~N}-\mathrm{NO}_{3}{ }^{-} /$fed. & $3.02 \mathrm{ab}$ & $3.08 \mathrm{~b}$ & $0.90 \mathrm{ab}$ & $0.98 \mathrm{a}$ \\
\hline \multirow{6}{*}{ 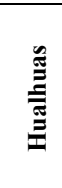 } & $40 \mathrm{~kg} \mathrm{~N}-\mathrm{NH}_{4}{ }^{+} /$fed. & $1.87 \mathrm{~g}$ & $2.25 \mathrm{f}$ & $0.67 \mathrm{e}$ & $0.73 \mathrm{~d}$ \\
\hline & $60 \mathrm{~kg} \mathrm{~N}-\mathrm{NH}_{4}^{+} /$fed. & $2.52 \mathrm{de}$ & $2.71 \mathrm{~d}$ & $0.80 \mathrm{~cd}$ & $0.85 \mathrm{bc}$ \\
\hline & $80 \mathrm{~kg} \mathrm{~N}-\mathrm{NH}_{4}{ }^{+} /$fed. & $3.2 \mathrm{a}$ & $3.05 \mathrm{~b}$ & $0.87 \mathrm{ab}$ & $0.91 \mathrm{~b}$ \\
\hline & $40 \mathrm{~kg} \mathrm{~N}-\mathrm{NO}_{3}{ }^{-} /$fed. & $1.86 \mathrm{~g}$ & $2.25 \mathrm{f}$ & $0.68 \mathrm{e}$ & $0.77 \mathrm{~d}$ \\
\hline & $60 \mathrm{~kg} \mathrm{~N}-\mathrm{NO}_{3}{ }^{-} /$fed. & $2.33 \mathrm{ef}$ & $2.69 \mathrm{~d}$ & $0.76 \mathrm{~d}$ & $0.85 \mathrm{bc}$ \\
\hline & $80 \mathrm{~kg} \mathrm{~N}-\mathrm{NO}_{3}{ }^{-} /$fed. & $3.02 \mathrm{ab}$ & $2.99 \mathrm{bc}$ & $0.84 \mathrm{bc}$ & $0.88 \mathrm{bc}$ \\
\hline
\end{tabular}

Table 5: Effect of cultivars and nitrogen rates of different sources on leaf moisture content and yield of quinoa plants harvested at 40 days after sowing, as a new leafy vegetable crop in the winter seasons of 2015 and 2016

\begin{tabular}{|c|c|c|c|c|c|}
\hline \multicolumn{2}{|r|}{ Treatments } & \multicolumn{2}{|c|}{ Leaf moisture content } & \multicolumn{2}{|c|}{ Yield $\left(\mathrm{kg} / \mathrm{m}^{2}\right)$} \\
\hline & & $1^{\text {st }}$ season & $2^{\text {nd }}$ season & $1^{\text {st }}$ season & $2^{\text {nd }}$ season \\
\hline \multicolumn{6}{|c|}{ Cultivars } \\
\hline \multirow{2}{*}{\multicolumn{2}{|c|}{$\begin{array}{l}\text { Cica } \\
\text { Hualhuas }\end{array}$}} & $70.23 \mathrm{a}$ & $68.04 \mathrm{a}$ & $1.68 \mathrm{a}$ & $1.76 \mathrm{a}$ \\
\hline & & $64.86 \mathrm{~b}$ & $68.54 \mathrm{a}$ & $1.27 \mathrm{~b}$ & $1.39 \mathrm{~b}$ \\
\hline \multicolumn{6}{|c|}{ Nitrogen rates of different sources $\left(\mathrm{N}-\mathrm{NH}_{4}{ }^{+} \text {or } \mathrm{N}-\mathrm{NO}_{3}\right)^{*}$} \\
\hline \multirow{6}{*}{\multicolumn{2}{|c|}{$\begin{array}{l}40 \mathrm{~kg} \mathrm{~N}-\mathrm{NH}_{4}^{+} / \text {fed. } \\
60 \mathrm{~kg} \mathrm{~N}-\mathrm{NH}_{4}^{+} / \text {fed. } \\
80 \mathrm{~kg} \mathrm{~N}-\mathrm{NH}_{4}^{+} / \text {fed. } \\
40 \mathrm{~kg} \mathrm{~N}-\mathrm{NO}_{3}^{-} / \text {fed. } \\
60 \mathrm{~kg} \mathrm{~N}-\mathrm{NO}_{3}^{-} / \text {fed. } \\
80 \mathrm{~kg} \mathrm{~N}-\mathrm{NO}_{3}^{-} / \text {fed. }\end{array}$}} & $64.06 \mathrm{C}$ & $69.74 \mathrm{~A}$ & $1.28 \mathrm{D}$ & $1.19 \mathrm{C}$ \\
\hline & & $68.30 \mathrm{~B}$ & $69.58 \mathrm{~A}$ & $1.46 \mathrm{C}$ & $1.61 \mathrm{~B}$ \\
\hline & & $71.09 \mathrm{~A}$ & $71.15 \mathrm{~A}$ & $1.87 \mathrm{~A}$ & $1.91 \mathrm{~A}$ \\
\hline & & $62.53 \mathrm{C}$ & $63.23 \mathrm{C}$ & $1.06 \mathrm{E}$ & $1.26 \mathrm{C}$ \\
\hline & & $68.25 \mathrm{~B}$ & $66.64 \mathrm{~B}$ & $1.38 \mathrm{C}$ & $1.55 \mathrm{~B}$ \\
\hline & & $71.03 \mathrm{~A}$ & $69.42 \mathrm{~A}$ & $1.78 \mathrm{~B}$ & $1.90 \mathrm{~A}$ \\
\hline \multicolumn{6}{|c|}{ Cultivars x Nitrogen rates of different sources } \\
\hline \multirow{6}{*}{ تِّ } & $40 \mathrm{~kg} \mathrm{~N}-\mathrm{NH}_{4}{ }^{+} /$fed. & $69.63 \mathrm{a}$ & $71.83 \mathrm{a}$ & $1.55 \mathrm{c}$ & $1.32 \mathrm{~d}$ \\
\hline & $60 \mathrm{~kg} \mathrm{~N}-\mathrm{NH}_{4}^{+} /$fed. & $70.20 \mathrm{a}$ & $70.49 \mathrm{abc}$ & $1.79 \mathrm{~b}$ & $1.84 \mathrm{~b}$ \\
\hline & $80 \mathrm{~kg} \mathrm{~N}-\mathrm{NH}_{4}^{+} /$fed. & $70.72 \mathrm{a}$ & $72.06 \mathrm{a}$ & $1.96 \mathrm{a}$ & $2.12 \mathrm{a}$ \\
\hline & $40 \mathrm{~kg} \mathrm{~N}-\mathrm{NO}_{3}^{-} /$fed. & $65.65 \mathrm{~b}$ & $60.69 \mathrm{f}$ & $1.20 \mathrm{~d}$ & $1.31 \mathrm{~d}$ \\
\hline & $60 \mathrm{~kg} \mathrm{~N}-\mathrm{NO}_{3}^{-} /$fed. & $73.12 \mathrm{a}$ & $64.97 \mathrm{e}$ & $1.53 \mathrm{c}$ & $1.80 \mathrm{bc}$ \\
\hline & $80 \mathrm{~kg} \mathrm{~N}-\mathrm{NO}_{3}^{-} /$fed. & $72.02 \mathrm{a}$ & $68.25 \mathrm{bcd}$ & $2.05 \mathrm{a}$ & $2.16 \mathrm{a}$ \\
\hline \multirow{6}{*}{ 吝 } & $40{\mathrm{~kg} \mathrm{~N}-\mathrm{NH}_{4}}^{+} /$fed. & $58.50 \mathrm{c}$ & $67.65 \mathrm{~cd}$ & $1.00 \mathrm{e}$ & $1.07 \mathrm{e}$ \\
\hline & $60 \mathrm{~kg} \mathrm{~N}-\mathrm{NH}_{4}^{+} /$fed. & $66.39 \mathrm{~b}$ & $68.67 \mathrm{bc}$ & $1.13 \mathrm{~d}$ & $1.38 \mathrm{~d}$ \\
\hline & $80 \mathrm{~kg} \mathrm{~N}-\mathrm{NH}_{4}^{+} /$fed. & $71.46 \mathrm{a}$ & $70.23 \mathrm{abc}$ & $1.79 \mathrm{~b}$ & $1.71 \mathrm{bc}$ \\
\hline & $40 \mathrm{~kg} \mathrm{~N}-\mathrm{NO}_{3}^{-} /$fed. & $59.41 \mathrm{c}$ & $65.77 \mathrm{de}$ & $0.93 \mathrm{e}$ & $1.20 \mathrm{de}$ \\
\hline & $60 \mathrm{~kg} \mathrm{~N}-\mathrm{NO}_{3}^{-} /$fed. & $63.37 \mathrm{~b}$ & $68.31 \mathrm{bcd}$ & $1.23 \mathrm{~d}$ & $1.31 \mathrm{~d}$ \\
\hline & $80 \mathrm{~kg} \mathrm{~N}-\mathrm{NO}_{3}^{-} /$fed. & $70.04 \mathrm{a}$ & $70.59 \mathrm{ab}$ & $1.52 \mathrm{c}$ & $1.65 \mathrm{c}$ \\
\hline
\end{tabular}

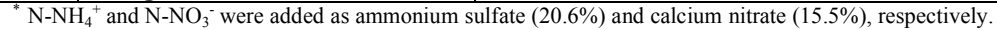

Means into every group within a column followed by the same letter are not significantly different $(P \leq 0.05)$ according to Duncan's multiple range test.

\section{REFERENCES}

Abd El-Rahman, M.M., R.A. El-Shabrawy, M.E. El-
Nasr and M.A. El-Saei (2001). Response of two spinach cultivars (Spinacia olerceae L.) to different 
$\mathrm{N}$-source and levels in relation on vegetative growth, yield, chemical composition, nitrate and oxalate. J. Agric. Sci., Mansoura Univ., 26(4): 2235-2262.

Abugoch, L.E. (2009). Quinoa (Chenopodium quinoa Willd.): Composition, chemistry, nutritional and functional properties. Adv. Food Nutr. Res., 58: 131.

AOAC (2005). "Official Methods of Analysis", $18^{\text {th }}$ ed. Association of Official Analytical ChemistsInternational (AOAC), Gaithersburg, Maryland, USA.

Basra, S.M.A., S. Iqbal and I. Afzal (2014). Evaluating the response of nitrogen application on growth, development and yield of quinoa genotypes. Int. J. Agric. Biol., 16(5): 886- 892.

Bhargava, A., S. Shukla and D. Ohri (2006). Chenopodium quinoa -an Indian perspective. Ind. Crop Prod., 23: 73- 87.

Bhargava, A., S. Shukla and D. Ohri (2007). Genetic variability and interrelationship among various morphological and quality traits in quinoa (Chenopodium quinoa Willd.). Field Crop Res., 101: 104-116.

Brinegar, C., B. Sine and L. Nwokocha (1996). Highcysteine $2 \mathrm{~S}$ seed storage proteins from Quinoa (Chenopodium quinoa). J. Agric. Food Chem., 44(7): 1621-1623.

Cavarianni, R. L., A. B. C. Filho, J. O. Cazetta, A. May and M.M. Corradi (2008). Nutrient contents and production of rocket as affected by nitrogen concentrations in the nutritive solution. Scientia Agricola, 65: 652-58.

Chochura, P. and E. Kolota (2011). The effect of nitrogen fertilization on radish yielding. Acta Sci. Pol., Hortorum Cultus, 10(1): 23-30.

Choukr-Allah, R., N.K. Rao, A. Hirich, M. Shahid, A. Alshankiti, K. Toderich S. Gill and K.U.R. Butt (2016). Quinoa for marginal environments: toward future food and nutritional security in MENA and Central Asia regions. Front Plant Sci., 7: 346.

Comai, S., A. Bertazzo, L. Bailoni, M. Zancato, C.V.L. Costa and G. Allegri (2007). The content of proteic and non proteic (free and protein-bound) tryptophan in quinoa and cereal flours. Food Chem., 100: 1350-1355.

Ebrahim, M.E.A., S.A. Hussin, A.A. Abdel-Ati, S.H. Ali and S.S. Eisa (2018). Evaluation of some Chenopodium quinoa cultivars under saline soil conditions in Egypt. Arab Univ. J. Agric. Sci., 26(1): 337-347.

Elia, A., P. Santamaria and F. Serio (1998). Nitrogen nutrition, yield and quality of spinach. J. Sci. Food Agric., 76: 341-346.

Erley, G.S.A., H.P. Kaul, M. Kruse and W. Aufhammer (2005). Yield and nitrogen utilization efficiency of the pseudocereals amaranth, quinoa and buckwheat under differing nitrogen fertilization. Eur. J. Agron., 22: 95-100.

Ezzo, M.I., A.A. Glala and S.M. Singer (2008). Influence of some alternative nitrogen sources and regimes on two salad cabbage cultivars. Aust. J.
Basic Appl. Sci., 2(3): 733-737.

Fageria, N.K., V.C. Baligar and R.B. Clark (2006). Physiology of crop production. The Haworth Press, New York, USA.

FAO (2013). Food and Agriculture Organizations of the United Nations. Rome, Italy, Launch of the international year of quinoa: UN celebrates Andean super food. http://www.fao.org/quinoa-2013/press room/news/detail/en/

Gallardo, M., J. González and F. Prado (2000). Presencia de betalaínas en plántulas de Chenopodium quinoa Willd. Lilloa, 40: 109-113.

Ghoulam, C., A. Foursy and K. Fares (2002). Effects of salt stress on growth, inorganic ions and proline accumulation in relation to osmotic adjustment in five sugar beet cultivars. Enviro. Exp. Bot., 47: 3950.

Gomez, K.A. and A.A. Gomez (1984). Statistical procedures for agriculture research $2^{\text {nd }}$ ed., Int. Science Publisher, John Wiley and Sons, New York, USA.

Gonzalez, J.A., Y. Konishi, M. Bruno, M. Valoy and F.E. Prado (2012). Interrelationships among seed yield, total protein and amino acid composition of ten quinoa (Chenopodium quinoa) cultivars from two different agroecological regions. J. Sci. Food. Agric., 92: 1222-1229.

Gülser, F. (2005). Effects of ammonium sulphate and urea on $\mathrm{NO}_{3}^{-}$and $\mathrm{NO}_{2}^{-}$accumulation, nutrient contents and yield criteria in spinach. Sci. Horti., 106: 330-340.

Hammad, S.A., M.A. Abou-Seeda, A.M. El-Ghamry and E.M. Selim (2007). Nitrate accumulation in spinach plants by using $\mathrm{N}$-fertilizer types in alluvial soil. J. Appl. Sci. Res., 3: 511-518.

Hariadi, Y., K. Marandon, Y. Tian, S.E. Jacobsen and S. Shabala (2011). Ionic and osmotic relations in quinoa (Chenopodium quinoa Willd.) plants grown at various salinity levels. J. Exp. Bot., 62: 185-193.

Hinsinger, P., C. Plassard, C. Tang and B. Jaillard (2003). Origins of root-mediated $\mathrm{pH}$ changes in the rhizosphere and their responses to environmental constraints: a review. Plant and Soil, 248: 43-59.

Jacobsen, S.E. (2003). The worldwide potential of quinoa (Chenopodium quinoa Willd.). Food Rev. Int., 19: 167-177.

Kansomjet, P., P. Thobunluepop, S. Lertmongkol, E. Sarobol, P. Kaewsuwan, P. Junhaeng, N. Pipattanawong and M.T. Ivan (2017). Response of physiological characteristics, seed yield and seed quality of quinoa under difference of nitrogen fertilizer management. Amer. J. Plant Physiol., 12: 20-27.

Koller, H.R.C. (1972). Leaf area-leaf weight relationships in the soybean canopy. Crop Sci., 12(2): 180-183.

Lincoln, T. and Z. Edvardo (2006). Assimilation of mineral nutrition. In: Plant physiology ( $4^{\text {th }}$ Ed.), Sinaur Associates, Inc. Pub., Sunderland, Sunderland, Miami, USA. 705p.

Madan, H. and R. Munjal (2009). Effect of split doses of nitrogen and seed rate on protein content, protein 
fractions and yield of wheat. J. Agric. Bio. Sci., 4(1): 26-31.

Marschner, H. (1995). Mineral nutrition of higher plants. Academic Press, London, UK.

Mirdad, Z.M. (2009). Spinach (Spinacia oleracea L.) growth and yield responses to irrigation dates, mineral nitrogen - sources and levels - application. J. Agric. Env. Sci. Alex. Univ., Egypt, 8(1): 43-69.

Mlakar, S.G., M. Turinek, M. Jakop, M. Bavec and F. Bavec (2010). Grain amaranth as an alternative and perspective crop in temperate climate. J. Geogr., 5(1): 135-145.

Modhej, A., A. Naderi, Y. Emam, A. Aynehband and G.H. Normohamadi (2008). Effects of post-anthesis heat stress and nitrogen levels on grain yield in wheat (T. durum and T. aestivum) genotypes. Int. J. Plant Prod., 2: 257-268.

Mujica, A., S.E. Jacobsen, J. Izquierdo and J. P. Marathee (2001). Resultados de la Prueba Americana y Europea de la Quinua. (pp. 51). FAO, UNA-Puno, CIP.

Neeteson, J.J., R. Booij and A.P. Whitemore (1999). A review on sustainable nitrogen management in intensive vegetable production systems. Acta Hort., 506: $17-26$

Patil, B.S., G.K. Jayaprakasha, K.N. ChidambaraMurthy and A. Vikram (2009). Bioactive compounds: historical perspectives, opportunities, and challenges. J. Agric. Food Chem., 57: 81428160.

Piotr, C. and E. Kołota (2011). Effect of differentiated nitrogen fertilization on the yield and quality of leaf lettuce. Folia Hort., 23(1): 61-66.

Pospisil, A., M. pospisil, B. Varga and Z. Svecnjak
(2006). Grain yield and protein concentration of two amaranth species (Amaranthus spp.) as influenced by the nitrogen fertilization. Eur. J. Agron., 25: 250-253.

Ravishankara, A.R., J.S. Daniel and R.W. Portmann (2009). Nitrous oxide $\left(\mathrm{N}_{2} \mathrm{O}\right)$ : the dominant ozonedepleting substance emitted in the $21^{\text {st }}$ century. Science, 326: 123-125.

Reay, D.S., E.A. Davidson, K.A. Smith, P. Smith, J.M. Melillo, F. Dentener and P.J. Crutzen (2012). Global agriculture and nitrous oxide emissions. Nature Climate Change, 2: 410-416.

Shaheen, A.M., Fatma A. Rizk, E.H. Abd El-Samad and Z.S.A. El-Shal (2012). Growth, yield and chemical properties of spinach plants as influenced by nitrogen fertilizer forms and micro-elements foliar application. J. Appl. Sci. Res., 8(2): 777-785.

Tapia, M.E. (2015). The long journey of Quinoa: who wrote its history? In: Bazile, D., Bertero, D., Nieto, C. (Eds.), State of the Art Report of Quinoa in the World in 2013. FAO \& CIRAD, Rome, pp. 3-9.

Toledo, M.E.A., Y. Ueda; Y. Imahori and M. Ayaki (2003). L-ascorbic acid metabolism in spinach (Spinacia oleracea L.) during postharvest storage in light and dark. Postharvest Biol. Technol., 28: 4757.

Vega-Gálvez, A., M. Miranda, J. Vergara, E. Uribe, L. Puente and E.A. Martínez (2010). Nutrition facts and functional potential of quinoa (Chenopodium quinoa Willd.), an ancient Andean grain: a review. J. Sci. Food Agric., 90: 2541-2547.

Wang, Z.H., Z.Q. Zong, S.X. Li and B.M. Chen (2002). Nitrate accumulation in vegetables and its residual in vegetable fields. Environ. Sci., 23: 79-83.

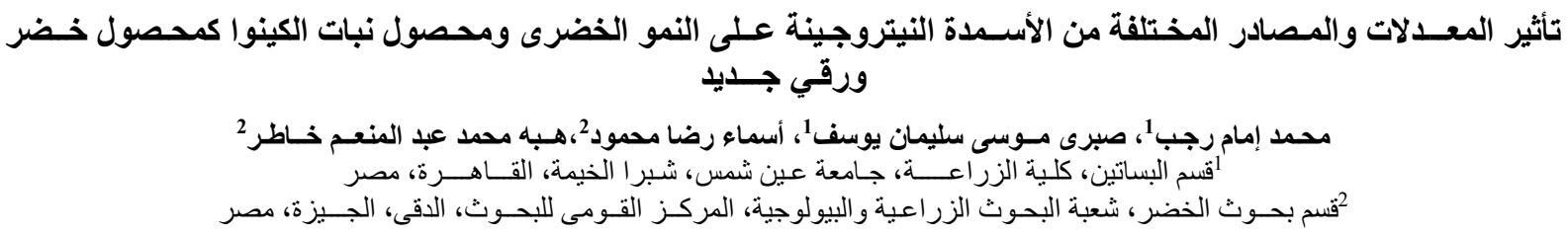

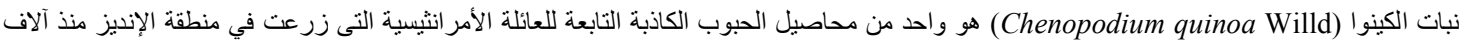

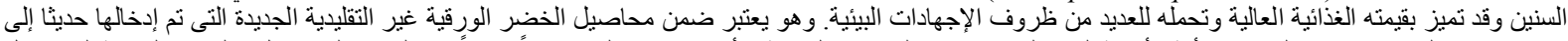

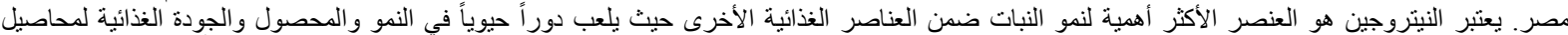

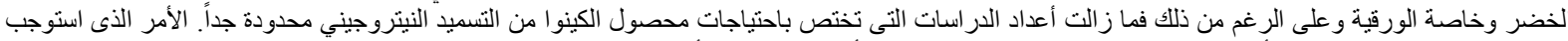

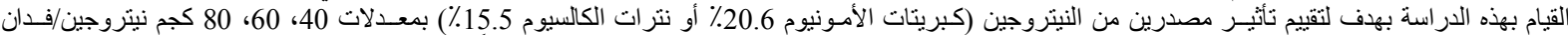

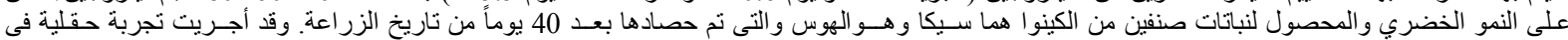

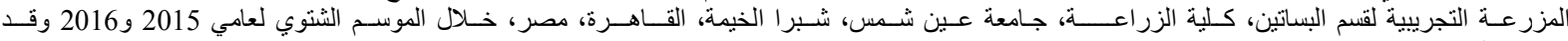

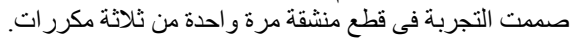

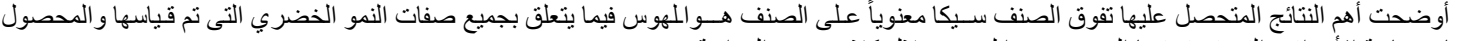

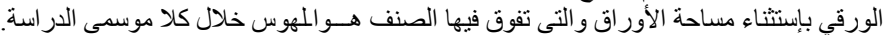

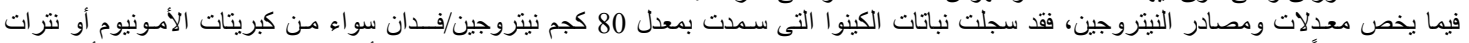

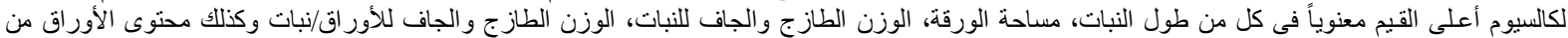

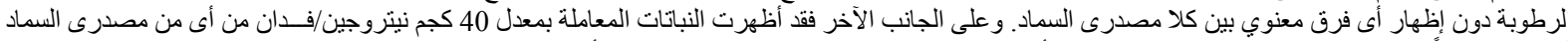

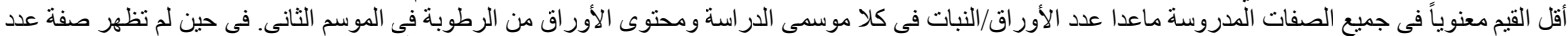

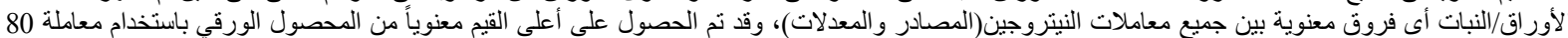

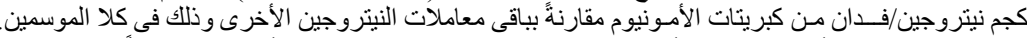

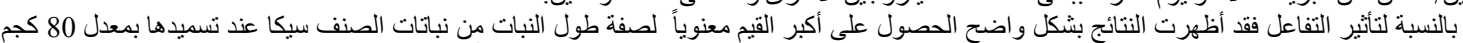

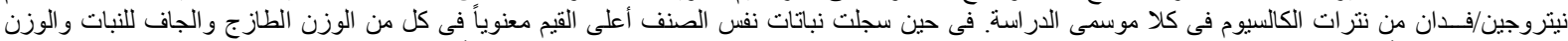

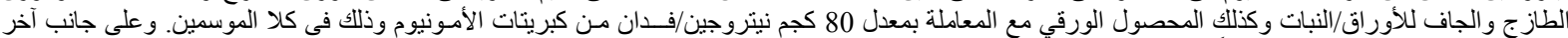

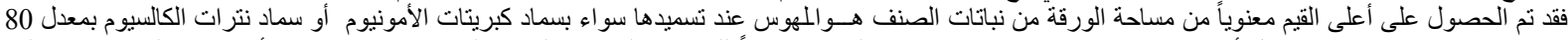

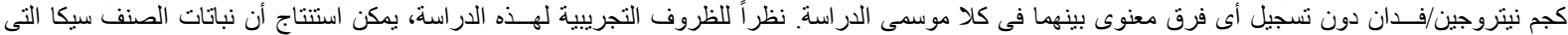

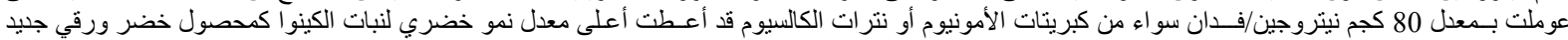
فى مصر وكذلك أعلى إنتاجية من المحصول الورقي. 